ACTA UNIVERSITATIS WRATISLAVIENSIS

No 3779

Studia nad Autorytaryzmem i Totalitaryzmem 39, nr 1

Wrocław 2017

DOI: $10.19195 / 2300-7249.39 .1 .9$

DARIUSZ SZPOPER

Uniwersytet Warmińsko-Mazurski w Olsztynie

\title{
„Kondycje mitawskie” i próba ograniczenia samodzierżawia w Imperium Rosyjskim na początku $1730 \mathrm{r}$.
}

Analizie pojęcia „samodzierżawie” („samowładztwo”) w polskiej literaturze historycznoprawnej - jak się zdaje - nie poświęcono do tej pory zbyt wiele miejsca. Jednym z nielicznych wyjątków może być tutaj fragment rozważań rosyjskiego historyka prawa o częściowo polskich korzeniach Teodora Taranowskiego (Fiodor Wasiliewicz Taranowskij), który po 1917 r. wyemigrował z Sankt Petersburga i osiadł w Belgradzie. Badacz ten na prośbę Przemysława Dąbkowskiego, pełniącego funkcję redaktora wydawanej we Lwowie serii „Pamiętnik Historyczno-Prawny" ", opublikował na jej łamach w 1928 r. pierwszą część Historii prawa rosyjskiego, poświęconą zagadnieniom ustrojowym, w której dokonał syntetycznego przeglądu faktów i wydarzeń stanowiących kolejne kroki na dziejowej drodze mającej finalnie doprowadzić do pełnego ukształtowania się takiego właśnie modelu władzy monarszej, charakterystycznego dla rosyjskiej państwowości².

Z kolei wybitny przedrewolucyjny historyk prawa Michaił Władimirskij-Budanow wskazywał, iż sam termin ,samodzierżawie” zaistniał w dobie panowania Iwana III, a zatem u schyłku XV w. w Państwie Moskiewskim i oznaczał: „nie tylko jedynowładztwo [...], ale i nieograniczoną pełnię praw"3. Po raz pierwszy słowem tym miał posłużyć się w 1492 r. niechlubnej pamięci metropolita Zosima, oskarżony następnie o herezję ${ }^{4}$, który w tekście zatytułowanym Izłożenije Paschalii określał wielkiego księcia Iwana Wasiliewicza mianem: „gosudara

1 T. Taranowski, Historia prawa rosyjskiego, cz. 1. Historia ustroju państwowego, „Pamiętnik Historyczno-Prawny" 1928, t. 1, z. 1, s. 3.

2 Ibidem, s. 57-61.

3 M.F. Władimirskiej-Budanow, Obzor istorii russkowo prawa, Moskwa 2005, s. 187.

${ }^{4}$ N. Talberg, Istorija Russkoj Cerkwi, Moskwa 2008, s. 211-212. 
i samodzierżawca wsieja Rusi" ${ }^{5}$. Natomiast w opinii Richarda S. Wortmana słowo „samodzierżawca” było dosłownym tłumaczeniem pochodzącego z języka greckiego sformułowania autocrator i oznaczało „nadrzędność cara moskiewskiego i jego suwerenność". Autor ten podkreśla zarazem, że nigdy wcześniej nie było takiej sytuacji, by władca Moskwy nie pozostawał w zależności od jakichkolwiek innych podmiotów zewnętrznych ${ }^{6}$. Dla samego Iwana IV Groźnego pojęcie „samodzierżawia” było pochodną boskiej legitymacji władzy monarszej, którą Stwórca powierza komu chce, wedle własnego uznania i woli. Konsekwencją przyjęcia takiego stanowiska stało się stwierdzenie, iż sprzeciw wobec władzy to także zakwestionowanie wyroków Boga, a tym samym grzech ciężki. Bez znaczenia dla Iwana Groźnego było to, czy władca rządził legalnie, zgodnie z prawem, czy też osiągnął swoją pozycję par force ${ }^{7}$. Twierdził bowiem, iż:

Ziemią włada miłosierdzie Boże i miłość przeczystej Bogarodzicy oraz modlitwy wszystkich świętych i błogosławieństwa naszych rodziców, a następnie my władcy swoi, a nie sędziowie i wojewodowie, czy też konsulowie i stratedzy ${ }^{8}$.

Istotą tej myśli było wskazanie, że władza carska stanowiła przedłużenie boskiego imperium i nikt poza monarchą legalnie nie może jej sprawować, tak paralelnie z nim, jak i zamiast niego. Takimi uprawnieniami mieli dysponować samowładcy rosyjscy, dla których samodzierżawie, w opinii Groźnego, było nie tylko przejawem pełni władzy, ale też osadzeniem jej w wymiarze teokratycznym oraz obudowaniem stanowionymi przez siebie normami prawa. Iwan IV pragnął jako samodzierżawca sprawować władzę samodzielnie, nie dopuszczając do udziału w niej zarówno bojarów, jak i prawosławnego kleru ${ }^{9}$. Po jego śmierci (19 marca 1584 r.) oraz doświadczeniach Wielkiej Smuty z lat 1598-1613, które oddziaływały na szerokie rzesze ludności ze wszystkich warstw i stanów społecznych - nie tylko w wymiarze rzeczywistym, lecz także transcendentnym oraz

${ }^{5}$ Cyt. za: R.S. Wortman, Scenarias of Power. Myth and Ceremony in Russian Monarchy, t. 1. From Peter the Great to the Death of Nicholas I, Princeton 1995 (korzystam z thumaczenia na język rosyjski dokonanego przez: S.W. Żitomirska, Scenarii własti. Mity i ceremonii russkoj monarchii, t. 1. Ot Petra Wielikowo do smerti Nikołaja I, Moskwa 2004, s. 42).

6 Ibidem, s. 46; podobnie patrz: N.M. Korkunow, Russkoje gosudarstwiennoje prawo, t. 1. Wwiedienije i obszcziaja czast', red. Z.D. Awałow, M.B. Gorenberg, K.N. Sokołow, S.[ankt] Petersburg 1908, s. 213 - Korkunow podkreśla międzynarodowy aspekt przyjęcia przez wielkiego księcia moskiewskiego Iwana III tytułu ,samodzierżawcy”; patrz też: P.E. Kazanskij, Włast ‘ Wsierossijkowo Imperatora, Moskwa 2007, s. 496 — autor podaje również, iż tytuł „samodzierżawiec” odpowiadał znajdującemu się w tytulacji cesarzy bizantyjskich słowu autocrator i przyjęcie go przez Iwana III miało oznaczać uniezależnienie się Wielkiego Księstwa Moskiewskiego od podległości wobec chanów tatarskich.

${ }^{7}$ W. Waldenberg, Drewnierusskije uczenija o predełach carskoj własti. Oczerki russkoj polityczeskoj literatury ot Władimira swiatowo do konca XVII wieka, Moskwa 2006, s. 275-276.

8 Cyt. za: W. Waldenberg, op. cit., s. 276.

9 Ibidem, s. 277; N.M. Korkunow, op. cit., s. 213. 
eschatologicznym - koncepcja samodzierżawia przeżywać zaczęła swój renesans pod rządami nowej rosyjskiej rodziny panującej - Romanowów ${ }^{10}$.

U schyłku panowania jednego $\mathrm{z}$ najwybitniejszych jej przedstawicieli Piotra I Wielkiego (1672-1725) - jego bliski współpracownik i zarazem osoba utożsamiająca się w pełni z poglądami władcy, arcybiskup wielkonowogrodzki i wielkołucki Teofan Prokopowicz ${ }^{11}$ pokusił się na sformułowanie definicji samodzierżawia. W wydanym w 1722 r. traktacie zatytułowanym Prawda woli monarszej $w$ opredelenii naslednika dierżawy swojej ${ }^{12}$ pod pojęciem samodzierżawcy ujął autokratę, który „nie jest obowiązany składać ze swych czynów sprawozdania nikomu na świecie i ma władzę rządzić swymi państwami i ziemiami według swej woli i rozumienia"13. Jedną z wiodących kategorii w jego rozważaniach nad istotą władzy samodzierżawnego monarchy była zasada troski o wspólne dobro poddanych, która jawiła się u Prokopowicza jako obowiązek panującego wypływający nie tylko z treści kontraktu łączącego go z ludem, lecz także z nakazu Boga, wyłącznie przed którym władca ponosi odpowiedzialność za wszelkie działania $^{14}$. Imperator, dla realizacji tego celu, wyposażony został w nieograniczone uprawnienia, jedynie z tym zastrzeżeniem, iż nie mogą one naruszać praw ustanowionych przez Boga. Sam miał określać, co jest desygnatem wspólnego dobra i czym jest prawda. Prowadzi to do całkowitej reglamentacji wszelkich przejawów aktywności jego poddanych, zarówno w sferze publicznej i prywatnej, jak i na niwie duchownej i świeckiej ${ }^{15}$. W koncepcji Teofana Prokopowicza podległy monarsze lud nie jest podmiotem jakichkolwiek praw, a obciążają go wyłącznie różnorakie obowiązki i bezkrytyczny nakaz podporządkowania się woli imperatora, nawet gdy w sferze moralnej i etycznej nie aprobuje poczynań i zachowań swojego władcy. Co więcej, poddanym nie przysługuje też ius resistendi i jedynie w wypadku wygaśnięcia dynastii — zgonu ostatniego jej reprezentanta, który odszedł, nie wydawszy żadnych dyspozycji publicznych mortis causa - lud ponownie staje się politycznym podmiotem, do którego ipso facto powracają uprawnienia przekazane niegdyś monarsze ${ }^{16}$.

10 P. Gonneau, A. Lavrov, Des Rhôs á la Russie. Histoire de l'Europe orientale (v. 730-1689), Paris 2012 (korzystam z thumaczenia M. Niekrasowa, E. Nosowej, Ot Rosow do Rossiji: Istorija Wostocznoj Jewropy [ok. 730-1689], Sankt Petersburg 2017, s. 212, 218).

11 A.G. Brikner (Brückner), Istorija Piotra Wielikowo, Moskwa 2004, s. 543; W. Cypin, Istorija Russkoj Prawostawnoj Cerkwii. Sinodalnyj i nowiejszij periody (1700-2005), Moskwa 2006, s. 19.

12 E. Timoszina, Feofan Prokopowicz, [w:] I.J. Kozlichin, A.W. Poliakow, E.W. Timoszina, Istorija politiczeskich i prawowych uczenij, Sankt Petersburg 2007, s. 538; E.W. Anisimow, Gosudarstwiennyje preobrazowanija i samodzierżawie Piotra Wielikowo, S.[ankt] Petersburg 1997, s. 274.

13 Cyt. za: Z. Jundziłł, Ustrój polityczny Imperium Rosyjskiego, Londyn 1949, s. 14.

14 E. Timoszina, op. cit., s. 544.

15 Ibidem, s. 544-545.

16 Ibidem, s. 546. 
Jednak zaledwie niespełna osiem lat po ukazaniu się traktatu pióra Teofana Prokopowicza i pięć lat po śmierci Piotra I w wymiarze praktyki politycznej doszło w Imperium Rosyjskim do pierwszej próby ograniczenia samodzierżawnej monarchii. Inspiracją dla tego wydarzenia stał się niespodziewany bezpotomny zgon młodego imperatora Piotra II, wnuka Piotra I, wraz z którym wygasła ostatecznie męska linia dynastii Romanowów ${ }^{17}$.

Piotr II (1715-1730) był synem carewicza Aleksieja Piotrowicza, skazanego w 1718 r. na karę śmierci, który to wyrok stanowił finał jego głośnego w ówczesnej Europie konfliktu z własnym ojcem, oraz księżniczki Charlotty Christiny Sophii von Braunschweig-Wolfenbüttel, pochodzącej z dynastii Welfów, notabene zmarkej zaledwie kilka dni po urodzeniu przyszłego imperatora ${ }^{18}$. W istocie rzeczy Piotr Aleksiejewicz nie odgrywał na dworze cesarskim przez dość długi czas samodzielnej roli politycznej, stanowiąc raczej swoistą kartę przetargową w rękach zarówno funkcjonujących tam koterii politycznych, jak i samej sukcesorki tronu jego dziadka - cesarzowej Katarzyny $\mathrm{I}^{19}$. Korona Imperium Rosyjskiego również trafiła $\mathrm{w}$ jego ręce niejako przypadkiem, kiedy w dniu zgonu Katarzyny I (6 maja 1727 r.) jej wszechwładny faworyt książę Aleksandr Daniłowicz Mieńszykow wymusił na konającej imperatorowej podpisanie testamentu, w którym czyniła swoim następcą wielkiego księcia Piotra Aleksiejewicza oraz zezwalała na wstąpienie przez niego w związek małżeński z księżniczką Marią Mieńszykow, córką inicjatora tego pomysłu. Bardzo szybko, bo pod koniec tego samego miesiąca (25 maja), doszło do uroczystych zaręczyn niezwykle młodego, bo mającego zaledwie 12 lat cesarza z jedynie trzy lata starszą od niego narzeczoną. Religijną oprawę ceremonii zapewnił arcybiskup Teofan Prokopowicz, który w imieniu Cerkwii prawosławnej parze tej błogosławi ${ }^{20}$. Akt ostatniej woli Katarzyny I przewidywał także, iż Piotr II aż do osiągnięcia 16. roku życia nie będzie mógł samodzielnie kierować nawą państwową - cesarzowa ustanawiała do tego momentu regentów w osobach: dwóch córek jej i Piotra I — wielkich księżnych Anny Piotrowny i Elżbiety Piotrowny, swojego zięcia księcia Karla Friedricha von Holstein-Gottorp, siostry młodego cesarza - wielkiej księżnej Natalii Aleksiejewny oraz członków Najwyższej Tajnej Rady (Wierchownyj Tajnyj Sowiet) ${ }^{21}$,

17 P. Grebielskij, A. Mirwis, Dom Romanowych. Biograficzeskije swedenija o czlenach carstwowawszego doma, ich predkach i rodstwiennikach, S.[ankt] Petersburg 1992, s. 48.

18 Ibidem, s. 47; N.I. Pawlenko, Istorija Piotra Wielikowo, Moskwa 2006, s. 382, 400.

19 E. Anisimow, Piotr II, [w:] Dynastia Romanowów, red. A. Iskenderow, Warszawa 1993, s. $132-133$.

20 Ibidem, s. 135; idem, Imperatorskaja Rossija, Moskwa-Sankt Petersburg-Mińsk 2016, s. 173; N.I. Pawlenko, Aleksandr Daniłowicz Mienszikow, Moskwa 1981, s. 134.

21 E. Anisimow, Piotr II..., s. 135; A.W. Demkin, Wnutriennaja politika Jekateriny I $i$ Wierchownowo Tajnowo Sowieta, Moskwa 2011, s. 38-41 — który informuje, iż Wierchownyj Tajnyj Sowiet został powołany imiennym ukazem cesarzowej Katarzyny I 8 lutego 1726 r., w którym wyjaśniała powody utworzenia tego organu sprowadzające się do poprawienia organizacji pracy prezydentów Kolegiów: Wojennego (Jaśnie Oświecony książę — swiatliejszij kniaź Aleksandr Da- 
w obradach której mógł uczestniczyć również małoletni imperator ${ }^{22}$. W istocie rzeczy Aleksandr Mieńszykow zdominował swoją osobą wszystkich pozostałych członków tego grona oraz starał się otoczyć poczynania swojego przyszłego cesarskiego zięcia niezwykle ścisłym nadzorem ${ }^{23}$. Permanentne usiłowania korekty jego zachowań i przyzwyczajeń budziły nie tylko opór Piotra II, lecz także daleko posuniętą niechęć wobec swojego protektora, na co dodatkowo nakładały się niezwykle chłodne relacje z jego córką i zarazem cesarską narzeczoną - księżniczką Marią Mieńszykową ${ }^{24}$. Finał tej sytuacji okazał się tragiczny dla Mieńszykowa - wraz z całą rodziną popadł w niełaskę imperatora, został zesłany we wrześniu 1727 r. do miejscowości Ranenburg (Oranienburg, współcześnie Czapłygin), następnie po zakończeniu trwającego śledztwa w marcu 1728 r. pozbawiono go wszelkich dóbr oraz majątku i nakazano osiedlić się wraz z żoną, dwiema córkami i synem w miejscowości Bierezow na Syberii, zezwalając jedynie na zabranie z sobą dziesięciu osób ze służby i wydzielając na utrzymanie wszystkich 5 rubli złotem na dobę $e^{25}$. Aleksandr Daniłowicz Mieńszykow zmarł tam w listopadzie 1729 r., przeżywszy niewiele swoją córkę Marię, która odeszła w wieku 18 lat, umierając w jego objęciach, i dla której zdążył jeszcze własnymi rękoma wykopać grób ${ }^{26}$.

Miejsce księcia Aleksandra Mieńszykowa w najbliższym otoczeniu Piotra II zajęli przedstawiciele wywodzącej się od Ruryka książęcej rodziny Dołgorukowó $^{27}$. Szczególnie bliskie relacje połączyły młodego imperatora z zaledwie siedem lat starszym od niego księciem Iwanem Aleksiejewiczem Dołgorukowem, który stał się dla swojego władcy niekwestionowanym autorytetem ${ }^{28}$. Faworyt cesarski wraz z ojcem księciem Aleksiejem Grigoriewiczem Dołgorukowem, dążąc

niłowicz Mieńszykow), Administracji (hr. Piotr Matwiejewicz Apraksin) i Spraw Zagranicznych (kanclerz Imperium Rosyjskiego, hr. Gawriła Iwanowicz Gołowkin), którzy weszli w skład Najwyższej Tajnej Rady. Oprócz nich, Katarzyna I powołała do pierwszego składu tejże Rady także rzeczywistych tajnych radców: hr. Piotra Andrejewicza Tołstoja, księcia Dmitrija Michajłowicza Golicyna oraz barona Heinricha Johanna Friedricha Ostermanna (Anriej Iwanowicz Osterman), wicekanclerza. Najwyższa Tajna Rada miała zbierać się raz w tygodniu w obecności imperatorowej oraz wypowiadać się co do kwestii polityki zagranicznej i wewnętrznej Imperium Rosyjskiego. W formalnej hierarchii urzędów zajmowała pozycję równorzędną z Senatem oraz pierwszymi Kolegiami: Wojennym, Admiralicji i Spraw Zagranicznych. Korespondencja pomiędzy nimi miała dokonywać się w formie promemoriów.

22 A.S. Aleksiejew, Silnyje persony w Wierchownom Tajnom Sowietie Piotra II i rol kniazia Golicyna pri wocarenii Anny Joannowny, Moskwa 2016, s. 17.

23 E. Anisimow, Piotr II..., s. 135.

24 P.W. Dołgorukow, Wriemia imperatora Piotra II i impieratricy Anny Joannowny, Moskwa 2008, s. 20.

${ }^{25}$ Ibidem, s. 22-23.

26 N.I. Pawlenko, Aleksandr Daniłowicz Mienszikow..., s. 184; E. Anisimow, Impieratorskaja Rossija..., s. 176 - autor jako jego datę śmierci podaje rok 1728; por. też P.W. Dołgorukow, op. cit., s. 23 .

27 M. Heller, Historia Imperium Rosyjskiego, Warszawa 2000, s. 362.

28 E. Anisimow, Piotr II..., s. 136. 
do utrwalenia własnych wpływów, podjęli działania mające na celu związanie się więzami rodzinnymi z dynastią Romanowów, doprowadzając do zaręczyn swej siostry i córki zarazem siedemnastoletniej księżniczki Katarzyny Aleksiejewny Dołgorukowej z Piotrem II. Pod koniec 1729 r. wiadomość została podana do publicznej wiadomości w Moskwie, w której przebywał monarcha wraz z dworem. Współczesny tym wydarzeniom Wasilij Aleksandrowicz Naszcziokin, jeszcze wówczas w randze podporucznika lefortowskiego pułku piechoty zanotował na kartach swoich Wspomnień, iż:

Tego roku, 19 listopada, Jego Cesarska Wysokość pozwolił wyznaczyć sobie narzeczoną, córkę księcia Aleksieja Grigoriewicza Dołgorukowa. Po tej dacie miały miejsce publiczne zaręczyny w Pałacu Gołowińskim, przy których obecna była babka Jego Wysokości caryca Jewdokija Fiedorowna. Zaręczynom przewodniczył arcybiskup nowogrodzki Teofan Prokopowicz, którą to ceremonię sam obserwowałem, pełniąc służbę ordynansa przy generale-feldmarszałku księciu [Wasiliju Władimirowiczu — D.S.] Dołgorukowie.

Niestety, niedługo po tym wydarzeniu fortuna przestała sprzyjać książętom Dołgorukowom - 6 stycznia 1730 r., także w Moskwie, po uroczystościach religijnych, którym towarzyszyły parady wojskowe z udziałem Piotra II, rozpoczął się finał jego panowania. Gdy wrócił bowiem do Pałacu Lefortowskiego, wystąpiły u niego objawy ospy. Choroba miała niezwykle skomplikowany i ciężki przebieg, ostatecznie doprowadzając po 12 dniach do agonii cesarza ${ }^{29}$ - Piotr II skonał w nocy z 18 na 19 stycznia 1730 r. w Pałacu Lefortowskim w Moskwie, przeżywszy niespełna 15 lat. $\mathrm{Z}$ jego śmiercią wygasła ostatecznie męska linia dynastii Romanowów ${ }^{30}$.

Późnym wieczorem 18 stycznia, gdy rozeszły się w Moskwie informacje o drastycznym pogorszeniu się stanu zdrowia imperatora, gremialnie do Pałacu Lefortowskiego zaczęli przybywać przedstawiciele generalicji, wysokiej rangi dostojnicy państwowi oraz arcybiskupi - ci ostatni przede wszystkim, aby towarzyszyć Piotrowi II w chwili śmierci, udzielając mu absolucji i ostatniego namaszczenia ${ }^{31}$. W tym gronie znaleźli się: Teofan Prokopowicz, Georgij Daszkow - metropolita rostowski, pochodzący ze starej rodziny bojarskiej, oraz arcybiskup twerski - Teofil (Teofitakt) Łopaciński (Lopatinskij), notabene urodzony w szlacheckiej rodzinie na Wołyniu, w granicach Rzeczypospolitej

29 W.A. Naszcziokin, Zapiski, [w:] J.P. Szachowskij, W.A. Naszcziokin, I.I. Nieplujew, Impieria posle Piotra 1725-1765, Moskwa 1998, s. 241.

30 M.M. Bogosłowskij, Konstitucjonnyje dwiżenije 1730 goda, [w:] idem, Rossijskij XVIII wiek, t. 2, Moskwa 2010, s. 53; W. Cypin, op. cit., s. 54 - badacz podaje też, że Piotr II jako ostatni z władców Imperium Rosyjskiego spoczął na moskiewskim Kremlu, w Soborze św. Michała Archanioła (Archangielskij sobor); co ciekawsze, wydarzenia te znalazły także swoje odzwierciedlenie w polskiej memuarystyce XVIII-wiecznej. Patrz szerzej S. Pilsztynowa, Proceder podróży i życia mego awantur, Kraków 1957, s. 104-109.

31 [T. Prokopowicz], Istorija o izbranii i wosszestwii na prestol blażennyja i wiecznodostojnyja pamiati Gosudaryni Impieratricy Anny Joannowny Samodzierżawcy Wsierossijskija soczinienije Teofana Prokopowicza 1730 god, Sankt Petersburg 1837, s. 3-4. 
Obojga Narodów ${ }^{32}$. Obecnych było także pięciu ministrów zasiadających wówczas w Najwyższej Tajnej Radzie: 1) hrabia Gawriła Iwanowicz Gołowkin kanclerz Imperium Rosyjskiego; 2) jego zastępca - baron Anriej Iwanowicz Osterman; a także członkowie rodu Dołgorukowów: 3) książę Aleksiej Grigoriewicz Dołgorukow; 4) książę Wasilij Łukicz Dołgorukow; jak też spokrewniony z nimi 5) książę Dmitrij Michajłowicz Golicyn. Szóstym jej członkiem pozostawał nienoszący tytułu ministra gubernator syberyjski książę Michaił Władymirowicz Dołgorukow, który brał również udział w tych wydarzeniach, przebywając w Moskwie w związku z planowanymi uroczystościami zaślubin jego krewnej księżniczki Katarzyny Dołgorukowowej z imperatorem Piotrem II — wydarzenie to było zaplanowane właśnie na 19 stycznia 1730 r. Rodzinę książąt Dołgorukowów reprezentowali także obecni tam: 1) generał-feldmarszałek książę Wasilij Władymirowicz Dołgorukow; 2) senator książę Iwan Grigoriewicz Dołgorukow; 3) faworyt zmarłego cesarza — książę Iwan Aleksiejewicz Dołgorukow. Spośród wielu osób tam obecnych w opracowaniach zachowały się jeszcze imiona oraz nazwiska: 1) feldmarszałka księcia Michaiła Michajłowicza Golicyna — starszego; 2) feldmarszałka księcia Michaiła Jurewicza Trubeckiego; 3) generała Iwana Ilicza Dmitriejewa Mamonowa; 4) generała Lwa Wasiliewicza Izmaiłowa; oraz 5) nadwornego koniuszego (sztalmejstra) Pawła Iwanowicza Jaguszinskiego ${ }^{33}$.

Kiedy trzech hierarchów Cerkwi prawosławnej opuściło już Pałac Lefortowski, wprowadzonych w błąd przez księcia feldmarszałka Dołgorukowa co do tego, iż debata o następstwie tronu Rosji odbędzie się dopiero ranem ok. godziny 10:00 i to w znacznie poszerzonym gronie, część pozostałych dygnitarzy przystąpiła do próby niezwłocznego rozwiązania tej kwestii ${ }^{34}$. Dwaj najbliżsi krewni niedoszłej carskiej małżonki, a więc jej ojciec — książę Aleksiej Grigoriewicz Dołgorukow — i brat — książę Iwan Aleksiejewicz Dołgorukow — przedłożyli nawet zgromadzonym fałszywy testament Piotra II, w którym rzekomo przekazywał on prawa do tronu swojej narzeczonej — księżniczce Jekaterinie Aleksiejewnie Dołgorukowej, domagając się zarazem realizacji tej ostatniej woli zmarłego imperatora $^{35}$. Żądanie to jednak napotkało opór pozostałych obecnych. Zaprotestował

32 A.W. Kartaszew, Istorija Russkoj Cerkwi, Moskwa 2005, s. 738; N. Talberg, op. cit., s. 559560; W. Cypin, op. cit., s. 53-54.

33 D.A. Korsakow, Wocarenije impieratricy Anny Joannowny, Kazań 1880, s. 3.

34 [T. Prokopowicz], op. cit., s. 5; A.D. Korsakow, op. cit., s. 4 - który podaje, że nie uczestniczyli w tych ustaleniach feldmarszałek ks. Michaił Juriewicz Trubeckij oraz generałowie: Iwan Ilicz Dmitriejew Mamonow i Lew Wasiliewicz Izmaiłow, a także część obecnych członków Senatu, oczekując w Pałacu Lefortowskim na podjęte decyzje.

35 [T. Prokopowicz], op. cit., s. 5-6; S. Płatonow, Russkaja istorija, Moskwa 2015, s. 380; E. Anisimow, Impieratorskaja Rossija..., s. 180; M.M. Bogosłowskij, op. cit., s. 54; D.A. Korsakow, op. cit., s. 4; I. Kurukin, Anna Iwanowna, Moskwa 2014, s. 49; [Ch.H. Manstein], Zapiski o Rossiji generała Mansztejna, [Moskwa] 2008, s. 181 - który podaje, że chwilę po śmierci Piotra II książę Iwan Aleksiejewicz Dołgorukow wyszedł z jego komnaty z obnażoną szpadą, wznosząc okrzyk: „Niech żyje cesarzowa Jekaterina”, którego jednak nikt z zebranych nie podjął. 
przeciwko tym planom pochodzący ze starej bojarskiej rodziny, początek swój biorącej jeszcze od wielkiego księcia litewskiego Giedymina, książę Dmitrij Michajłowicz Golicyn, który wskazał na fakt wygaśnięcia ze śmiercią wnuka Piotra I męskiej linii dynastii Romanowów oraz zanegował prawa dynastyczne do tronu Imperium Rosyjskiego córek Katarzyny I, argumentując to jej plebejskim pochodzeniem. W sukurs przyszedł mu feldmarszałek książę Wasilij Władymirowcz Dołgorukow, który podkreślił, iż są jeszcze pretendentki do tronu z żeńskiej linii Romanowów. W tym kontekście wskazywał na żyjącą jeszcze wdowę po Piotrze I i zarazem jego pierwszą małżonkę carycę Jewdokię Fiedorowną, z którą łączyły go więzy przyjaźni i interesy ${ }^{36}$. Kandydatura ta nie przypadła z kolei do gustu księciu Dmitrijowi Golicynowi — w odpowiedzi podkreślił on, iż Jewdokia Fiedorowna to zaledwie wdowa po imperatorze, a przecież są jeszcze kobiety reprezentujące starszą gałąź carskiej rodziny. Także z prawnego punktu widzenia pomysł osadzenia na tronie Jewdoki Fiodorowny wydawał się dosyć ryzykowny — po rozpadzie jej związku małżeńskiego z Piotrem I złożyła ona śluby zakonne i przebywała w klasztorze prawosławnym jako mniszka ${ }^{37}$.

$\mathrm{W}$ toku dalszej dyskusji upadła kandydatura starszej córki cara Joanna V Aleksiejewicza - Jekateriny Joannowny, wydanej w 1717 r. z przyczyn politycznych przez Piotra I za mąż. Była ona małżonką księcia Karla Leopolda von Mecklenburg-Schwerin. W opinii Dmitrija Michajłowicza Golicyna sama Jekaterina jawiła mu się jako „,dobra kobieta, lecz jej mąż, książę meklenburski, [był — D.S.] zły i pozbawiony rozumu"38. Najmłodsza z trzech żyjących córek Joanna V Praskowija - pozostawała natomiast w związku morganatycznym z senatorem i zarazem generałem-anszefem (general en chef) Iwanem Iliczem Dmitrijewem-Mamonowem, co automatycznie niejako wykluczało jej kandydaturę do korony rosyjskiej ${ }^{39}$. W tej sytuacji właściwie pozostawała wyłącznie osoba jednej pretendentki do tronu Imperium Rosyjskiego — wdowy po księciu Kurlandii i Semigalii Fryderyku Wilhelmie Kettlerze i zarazem średniej córki Joanna $\mathrm{V}$ — księżnej Anny Joannowny ${ }^{40}$. W opinii księcia Dmitrija Golicyna, który wystąpił z tą propozycją, była ona ponadprzeciętną osobowością, chociaż - jak zaznaczał - charakteryzowały ją nader złożone i trudne cechy charakterologiczne, przy czym dodawał, iż: „w Kurlandii nie ma z niej niezadowolenia”. Golicyna poparł nieoczekiwanie książę Wasilij Łukicz Dołgorukow ${ }^{41}$, który w sukcesie tej kandydatury upatrywał

36 D.A. Korsakow, op. cit., s. 4; P.W. Dołgorukow, op. cit., s. 41-42.

37 M.M. Bogosłowskij, op. cit., s. 54; szerzej o Jewdoki (Praskowi) Fidorownie z Łopuchnikow patrz P. Grebielskij, A. Mirwis, op. cit., s. 123-124.

38 D.A. Korsakow, op. cit., s. 4; P. Grebielskij, A. Mirwis, op. cit., s. 130.

39 M.M. Bogosłowskij, op. cit., s. 55; P. Grebielskij, A. Mirwis, op. cit., s. 131.

40 M.M. Bogosłowskij, op. cit., s. 56; O. Agiejewa, Impieratrica Wsierossijskaja Anna Joannowna 28 janwaria 1693-17 oktiabria 1740, Moskwa 2015, s. 16.

41 D.A. Korsakow, op. cit., s. 5. 
szansę na realizację własnych ambicji politycznych, jak się wydaje, nie do końca zbieżnych z planami pozostałych członków jego rodziny ${ }^{42}$.

Po osiągnięciu konsensusu co do osoby przyszłego monarchy członkowie Najwyższej Tajnej Rady kontynuowali rozmowy. Z ideowego oraz ustrojowego punktu widzenia, być może, ta część wymiany poglądów wydaje się co najmniej równie istotna jak rozstrzygnięta uprzednio kwestia osoby nowego monarchy.

Ponownie głos zabrał książę Dmitrij Michajłowicz Golicyn, który miał wyrzec wówczas znamienne słowa: „Jest wolą Waszą [...], kogo raczycie [wybrać — D.S.], tylko należy sobie polepszyć". W odpowiedzi kanclerz hrabia Gawriła Gołowkin pytał: „Jak to polepszyć?”, na co książę Dmitrij Golicyn odpowiedział: „Tak polepszyć, ażeby wolność swoją poszerzyć". Wypowiedź tę skomentował książę Wasilij Łukicz Dołgorukow, który sceptycznie zauważył: „Jeżeli nawet i zaczniemy, to nie podtrzymamy tego". Ripostował książę Golicyn, mówiąc, iż: „Prawo obronimy!” Widząc zaś niezdecydowanie pozostałych obecnych, dodawał: „Niech się stanie wola Wasza, tylko trzeba spisać i wysłać do Jej Wysokości punkty”43.

Nie bez pewnych obaw przystąpiono zatem do ich zredagowania. Prym wiedli tutaj wspólnie książęta Wasilij Dołgorukow i Dmitrij Golicyn, którzy posiłkowani przez innych obecnych dygnitarzy dyktowali ich brzmienie urzędnikowi kancelarii Najwyższej Tajnej Rady Wasiliejowi Stiepanowowi. W jego relacji odbywało się to dość spontanicznie i chaotycznie zarazem, tak iż zauważał, że „nie wiedział, co pisać”. Poproszono o współpracę oraz wystylizowanie treści pierwszej wersji kondycji wicekanclerza barona Andrieja Iwanowicza Ostermana, który jednak merytorycznie nie chciał się do tych politycznych propozycji ustosunkować, zasłaniając się tym, iż jest cudzoziemcem ${ }^{44}$.

Ostatecznie powstała wówczas początkowa wersja pisma. Składała się ze swoistej preambuły, w której imperatorowa oświadczała, iż będzie otaczać troską i zabiegać o rozprzestrzenianie się ,prawosławnej naszej wiary wyznania greckiego", a ponadto oznajmiała niezbędność swojej współpracy z członkami Najwyższej Tajnej Rady, albowiem „integralność i sukces jakiegokolwiek państwa

42 P.W. Dołgorukow, op. cit., s. 42 - który informuje, iż książę Wasilij Łukicz Dołgorukow, pełniąc funkcję rezydenta w Mitawie i przebywając tam przez kilka tygodni, poznał księżnę Annę Joannowną, a nawet nawiązały się pomiędzy nimi pewne relacje towarzyskie. Liczył na ich odtworzenie po objęciu przez nią tronu Imperium Rosyjskiego, ale też na pewnego rodzaju uzależnienie od siebie przyszłej monarchini.

43 D.A. Korsakow, op. cit., s. 5; podobnie patrz P.W. Dołgorukow, op. cit., s. 42; M.M. Bogosłowskij, op. cit., s. 55; [W.Ł. Dołgorukow], Iz pokazanij W.t. Dołgorukowa, [dat.] 6 nojabria 1739 goda, [w:] I.W. Kurukin, A.B. Płotnikow, 19 janwaria - 25 fewralia 1730 goda: sobytia, liudzi, dokumenty, Moskwa 2010, s. 184, dokument nr 49.

44 [W.W. Stiepanow], [Zapiska W.W. Stiepanowa], [w:] I.W. Kurukin, A.B. Płotnikow, op. cit., s. 188. Autorowi niniejszego tekstu nie udało się ustalić pełnego brzmienia otczestwa Wasilija Stepanowa, albowiem Korsakow (idem, op. cit., s. 8) podaje, iż był to Wasilij Pietrowicz Stiepanow, zaś Filipow (idem, Istorija Senata w prawlenije Wierchownowo Tajnowo Sowieta i Kabineta, cz. 1. Senat w prawlenije Wierchownowo Tajnowo Sowieta, Juriew 1895, s. 44) oraz współcześnie podobnie Demin (idem, op. cit., s. 41 i passim) używają wyłącznie imienia i nazwiska Wasilij Stiepanow. 
zależny jest od dobrych rad". Dlatego też cesarzowa Anna Joannowna godziła się na to by, samodzielnie, bez aprobaty Najwyższej Tajnej Rady:

1) nikomu wojny nie wypowiadać; 2) pokoju nie zawierać; 3) nie obciążać nowymi podatkami swoich wiernych poddanych; 4) do znaczących godności tak cywilnych, jak i wojskowych, lądowych oraz morskich, powyżej stopnia pułkownika — nie mianować, zaś poniżej tych rang do prowadzenia prestiżowych spraw nikogo nie wyznaczać; 5) nie pozbawiać szlachty życia, czci i majątku bez wyroku sądu; 6) nie nadawać wotczyn i wsi; 7) z państwowych dochodów i wydatków nie korzystać, a ponadto otaczać wszystkie sobie poddane osoby swoją łaską ${ }^{45}$.

Współcześni rosyjscy autorzy podkreślają, iż ideowej genezy tych poglądów należy poszukiwać w szerokiej perspektywie europejskiego Oświecenia, zarówno na niwie ustrojowej, jak i filozofii politycznej. W tym kontekście przywołuje się zmierzającą ku konstytucjonalizmowi reformę formy rządu w Szwecji, jednocześnie nie zapominając o wpływie, jaki mogła wywierać — przynajmniej na część arystokracji rosyjskiej - szkoła prawa natury, szczególnie w osobie Samuela von Pufendorfa, którego poglądy znane były z tłumaczeń jego prac zleconych jeszcze przez Piotra $\mathrm{I}^{46}$. Traktat pióra Pufendorfa zatytułowany O obowiązach człowieka $i$ obywatela wedtug prawa natury [O dotżnosti czełowieka i grażdanina po zakonu jesties 'twiennomu] ukazał się drukiem w 1726 r. w Sankt Petersburgu, zaś egzemplarze tego dzieła znalazły się w bibliotekach dygnitarzy czynnie zaangażowanych w wydarzenia polityczne następujące po zgonie imperatora Piotra II, chociażby księcia Dmitrija Michajłowicza Golicyna, barona Andrieja Iwanowicza Ostermana czy też arcybiskupa Teofana Prokopowicza. Pufendorf odrzucał koncepcję boskiej kreacji państwa, stojąc na stanowisku, iż jest ono wytworem ludzkim, a tym samym władza nad zamieszkującym w jego granicach społeczeństwem nie należy wyłącznie do osoby powołanej do jej sprawowania przez Boga, czyli do monarchy wzmacnianego w swych działaniach autorytetem Kościoła, lecz także do ludu, który wspólnie dysponuje nie tylko czymś w rodzaju inicjatywy ustawodawczej, lecz także wręcz uprawnieniem do stanowienia obowiązujących powszechnie norm prawnych.

Samuel von Pufendorf obudowywał swoje przemyślenia nad wyraz interesującą koncepcją umowy społecznej, u podstaw której widział dwa kontrakty

${ }^{45}$ Kondycji, ogranicziwajuszcziji wtast' monarcha w polzu Tajnowo Wierchownowo Sowieta, dat. [Moskwa], 18 janwaria 1730 g.[oda], [w:] Konstitucionyje projekty w Rossiji XVIII — naczała XX wieka, red. A.N. Mieduszewskij, Moskwa 2010, s. [75]; por. też D.A. Korsakow, op. cit., s. 8-9; I.W. Kurukin, Reformy i reformatory „epochi dworcowych piereworotow”, [w:] Reformy w Rossiji s drewniejszych wriemion do konca XX wieka, t. 2. XVIII - pierwaja połowina XIX wieka, red. A.B. Kamienskij, Moskwa 2016, s. 97-98.

46 E.W. Anisimow, Gosudarstwiennyje preobrazowanija..., s. 274; patrz także J. M.[alczewski], Pufendorf Samuel von..., [w:] Stownik historii doktryn politycznych, t. 4, red. K. Chojnicka, M. Jaskólski, Warszawa 2009, s. 789 — który podaje pełny tytuł oryginału tego dzieła: S. Pufendorf, De Officio Hominis et Civis Prout Ipsi Praescribuntur Lege Naturali Libri Duo (1673), które przetłumaczone w wielu krajach na języki narodowe stało się popularnym dziełem, z którego korzystała nie tylko młodzież akademicka. 
bazowe: pierwszy z nich miałby łączyć jednostki w celu zagwarantowania sobie bezpieczeństwa oraz określałby tryb i sposób sprawowania rządów, zaś w ramach drugiego przystępujące do niego podmioty działające wspólnie w formie bez mała zinstytucjonalizowanej grupy wolą jej większości poddawałaby się zależności władczej od wykreowanego przywódcy, którą to funkcję mogłaby pełnić zarówno osoba fizyczna, jak i pewnego rodzaju zbiorowość. Twórca tych założeń preferował jednak przede wszystkim system monarchiczny, dostrzegając jego daleko posuniętą wyższość nie tylko nad porządkiem arystokratycznym, ale też demokratycznym, podkreślając jednak zarazem potrzebę ustanowienia przez poddanych reguł dotyczących sukcesji korony oraz tronu — zagadnienie to musiało być bezwzględnie uregulowane $\mathrm{w}$ sposób niebudzący wątpliwości, a zatem w miarę precyzyjnie i jasno ${ }^{47}$. Pufendorf ponadto $\mathrm{w}$ swych rozważaniach aprobował możliwość zawężenia suwerenności przyjętymi regułami postępowania, określonymi aktami normatywnymi rangi fundamentalnej, których przepisy wyznaczałyby procedury dotyczące konieczności dokonywania uzgodnień z wszelkiego rodzaju instytucjami o charakterze kolektywnym i przedstawicielskim zarazem. Ograniczając istotę suwerenności poprzez zawężenie przyjmowanego przy jej realizacji modelu proceduralnego, Pufendorf stał jednak na stanowisku, iż tym sposobem w żadnym razie „supremacja suwerenności nie zostaje podważona”48.

Rankiem 19 stycznia rozpoczął się dalszy etap prac nad ostateczną redakcją punktów, które miała zaakceptować księżna kurlandzka Anna Joannowna przed objęciem tronu Imperium Rosyjskiego. Miał on miejsce na Kremlu, w pomieszczeniu Masterskoj pałaty, w której zwykle obradowała Najwyższa Tajna Rada. Poza częścią jej członków (nieobecni byli książę Aleksij Grigoriewicz Dołgorukow i Andriej Osterman) zgromadzili się tam również przedstawiciele duchowieństwa, szlachty, dostojnicy państwowi i dworscy oraz generalicja. Zaakceptowali oni dokonany wybór nowej cesarzowej Anny Joannowny. Uczestniczący w tym wydarzeniu arcybiskup Teofan Prokopowicz pisał: „wówczas wszyscy jednogłośnie wyrazili swoją zgodę i nie było nikogo, kto by w ogóle o tym przemyśliwał"49. Zaproponował też w imieniu obecnych hierarchów Cerkwi prawosławnej odprawienie uroczystej liturgii za dar nowego panowania w Soborze Preobrażeńskim na Kremlu, co jednak nie spotkało się z aprobatą obecnych członków Najwyższej Tajnej Rady ${ }^{50}$. W opinii Teofana Prokopowicza decyzja ta wzbudziła zdumienie i zarazem pewną refleksję sprowadzającą się do tego, iż „wielu zaczęło się zastanawiać, co spowodowało, że wierchownicy odrzucili ową modlitwę dziękczynną?" Odpowiedź miała nasuwać się sama i brzmieć, że członkowie Najwyższej Tajnej Rady

${ }^{47}$ I.W. Kurukin, op. cit., s. 99.

48 D. Boucher, Burke, [w:] Myśliciele polityczni. Od Sokratesa do wspótczesności, red. D. Boucher, P. Kelly, przeł. A. Dąbrowska, T. Sieczkowski, Kraków 2008, s. 499-500.

49 F. Prokopowicz, op. cit., s. 7-8.

50 Ibidem, s. 8; D.A. Korsakow, op. cit., s. 11. 
tworzyli inny aniżeli poprzednio funkcjonujący model władzy carskiej i że podczas owej nocnej dyskusji w nielicznym swym gronie zaczęli, najprościej mówiąc, jakimiś wydumanymi koncepcjami ograniczać czy wręcz likwidować samodzierżawie ${ }^{51}$.

Po pożegnaniu duchowieństwa nadal toczyły się prace nad finalnym brzmieniem posłania kierowanego do Mitawy. Wyłoniono również skład delegacji, która miała się tam udać. Znalazły się w niej trzy osoby: książę Wasilij Łukicz Dołgorukow, którego atutem była wcześniejsza znajomość z Anną Joannowną, generał książę Michał Michajłowicz Golicyn — młodszy (obaj zaproponowani przez starszego brata tego ostatniego księcia Dmitrija Michajłowicza Golicyna) oraz wysunięty przez kanclerza Gawryłę Iwanowicza Gołowkina krewny jego i zarazem matki Piotra I poprzez rodzinę Naryszkinów — generał Michał Iwanowicz Leontiew $^{52}$. Członkowie Najwyższej Tajnej Rady udzielili także instrukcji uczestnikom kierowanej do Mitawy deputacji, której zasad mieli bezwzględnie przestrzegać. Jej treść (sam dokument nie zachował się) udało się odtworzyć rosyjskiemu historykowi z przełomu XIX i XX w. Dmitrijowi Aleksandrowiczowi Korsakowowi. Składała się ona z 10 punktów, w treści których nakazywano: 1) wręczenie tekstu kondycji Annie Joannownie osobiście, bez asysty kogokolwiek innego; 2) uważać na to, by nie przekazano jej innych informacji z Moskwy aniżeli te, które przyniosła oficjalna delegacja; 3) wyjaśnić przyszłej cesarzowej, iż treść kondycji została oparta na woli i potrzebach całego „narodu rosyjskiego”, pod którym to pojęciem zgodnie z zasadami funkcjonującymi w początkach XVIII stulecia rozumiano jedynie wyższe warstwy społeczeństwa; 4) uzyskać pewność, że warunki przedstawione Annie Joannownie zostały przez nią przyjęte i z jej strony widoczna jest chęć ich wypełnienia; 5) po podpisaniu przez nią dokumentu, w treści którego znalazły się kondycje, niezwłocznie dostarczyć go do Moskwy, co miał uczynić jeden z członków delegacji; 6) podjąć działania na rzecz pozostawienia w Mitawie bliskiego przyszłej cesarzowej kamerjunkra Ernesta Birona; 7) naciskać na szybki przyjazd Anny Joannowny do Moskwy, do którego to momentu nie zostanie podany do publicznej wiadomości zarówno fakt zgonu imperatora Piotra II, jak i decyzja o objęciu przez nią tronu rosyjskiego; 8) informować Najwyższą Tajną Radę o wszystkich działaniach podjętych przez delegatów w Mitawie, lecz także o przebiegu podróży Anny Joannowny z Kurlandii do Rosji; 9) czynić wszystko, by w tym wydarzeniu towarzyszyli jej członkowie delegacji, a nie by trasę pokonywała samodzielnie; 10) troszczyć się o to, żeby całą wyprawę otoczyć ścisłą

51 F. Prokopowicz, op. cit., s. 8-9.

52 Protokót zasiedanij Wierchownowo tajnowo sowieta sodierżawszij rieszenije ob izbranii na rossijskij prestot cariewny Anny Iwanowny i utwierżdiennyj wierchownikami tekst predjawliajemych ejej „kondicij”, dat. [Moskwa], 19 janwaria 1730 g.[oda], [w:] I.W. Kurukin, A.B. Płotnikow, op. cit., s. 118-119, dokument nr 1; F. Prokopowicz, op. cit., s. 15; D.A. Korsakow, op. cit., s. 13; M.M. Bogosłowskij, op. cit., s. 56. 
tajemnicą i by żadne informacje na ten temat nie przedostały się ani do Sankt Petersburga, ani też nie przeniknęły do wiadomości zagranicznych dworów ${ }^{53}$.

Późnym wieczorem 19 stycznia 1730 r. książę Wasilij Łukicz Dołgorukow otrzymał ostateczną wersję kondycji wraz z listem do przyszłej cesarzowej oraz z kluczem do szyfru, niezbędnym do utrzymywania korespondencji z Najwyższą Tajną Radą. Bezzwłocznie po tym delegacja opuściła Moskwę, udając się do Mitawy, w której rezydowała Anna Joannowna ${ }^{54}$.

W treści przesłania podpisanego przez sześciu członków Najwyższej Tajnej Rady informowano Annę Joannowną o zgonie Piotra II i decyzji, zarówno ich, jak i „duchownych i różnej rangi świeckich ludzi”, którzy chcieliby przekazać jej tron rosyjski pod warunkiem podpisania kondycji dostarczonych do Mitawy przez wysłaną tam w tym celu delegację oraz niezwłocznego opuszczenia Kurlandii i przyjazdu do Moskwy ${ }^{55}$. Treść dokumentu, który Anna Joannowna miała własnoręcznie sygnować, brzmiała:

Ponieważ taka jest wola Boga i wspólne oczekiwanie ludu rosyjskiego, my kierując się wskazaniami najświetlejszego, panującego, wielkiego władcy Piotra Drugiego, imperatora i samodzierżawcy wszechrosyjskiego, naszego ukochanego krewnego monarchy, przyjęliśmy wszechrosyjski cesarski tron, i kierując się prawem bożym, rządy swoje w taki sposób zamierzam sprawować i pragnę, ażeby owe przede wszystkim służyć mogły chwale boskiego imienia i szczęśliwości całego naszego państwa i wszystkich naszych poddanych. Dlatego też, w sposób najbardziej silny zapewniamy, iż najistotniejszą moją troską i działaniem będzie nie tylko utrzymanie, ale także jak najdalsze i możliwe rozszerzenie prawosławnej naszej wiary obrządku greckiego, również po przyjęciu korony rosyjskiej w związek małżeński do końca życia nie wstępować i następcy ani za życia, ani też po sobie nie wyznaczać. Ponadto zapewniamy, że ponieważ całość i szczęście jakiegokolwiek państwa zależy od cennych rad, dlatego my teraz już istniejącą ośmioosobową Najwyższą Tajną Radę zawsze utrzymywać [zamierzamy — D.S.] i bez zgody tejże Najwyższej Tajnej Rady: 1) z nikim wojny nie wszczynać; 2) pokoju nie zawierać; 3) wiernych naszych poddanych jakimikolwiek nowymi podatkami nie obciążać; 4) istotnych rang, tak państwowych, jak i wojskowych, w piechocie i marynarce, powyżej stopnia pułkownika, nie nadawać, a poniżej nie wyznaczać do kierownika najważniejszymi sprawami, zaś gwardii i innym wojskom pozostawać pod komendą Najwyższej Tajnej Rady; 5) szlachty nie karać śmiercią, utratą dóbr i czci bez wyroku sądu; 6) nie nadawać wotczyn i wsi; 7) urzędy dworskie zarówno Rosjanami, jak i cudzoziemcami nie obsadzać bez zasięgnięcia opinii Najwyższej Tajnej Rady; 8) z państwowych dochodów nie korzystać i wszystkich swoich wiernych poddanych otaczać niezmienną własną miłością, a jeżeli czegoś z tych przyrzeczeń nie wypełnię i nie dotrzymam, to będę pozbawiona korony rosyjskiej ${ }^{56}$.

53 D.A. Korsakow, op. cit., s. 13-14.

54 Ibidem, s. 16-17.

55 Pismo Wierchownowo tajnowo sowieta Annie Joannownie s izwieszczenijem ob izbranii jejo na prestol, dat. [Moskwa] 19 genwarja 1730 goda, [w:] I.W. Kurukin, A.B. Płotnikow, op. cit., s. 121, dokument $\mathrm{nr} 2$ — pod jego treścią widnieją podpisy: 1) hr. Gawryły Gołowkina — kanclerza; 2) ks. Michaiła Michajłowicza Golicyna; 3) ks. Wasilija Władymirowicza Dołgorukowa; 4) ks. Dmitrija Michajłowicza Golicyna; 5) barona Andrieja Ostermana — wicekanclerza; 6) ks. Aleksieja Grigoriewicza Dołgorukowa.

56 Protokot zasiedanij Wierchownowo tajnowo sowieta, sodierżawszij reszenijć ob izbranii na rossijskij prestot cariewny Anny Iwanowny..., s. 119-120; D.A. Korsakow, op. cit., s. 17-18; 
Najwyższa Tajna Rada zadbała także o umożliwienie w miarę szybkiego oraz pozbawionego przeszkód przejazdu dla swoich pełnomocników udających się do Mitawy, organizując na odcinku pomiędzy Moskwą a Rygą po 30 podwód, zaś następnie do stolicy Kurlandii kolejne wypoczęte wierzchowce w liczbie niezbędnej do szybkiego przebycia tego dystansu. Kolegium Spraw Zagranicznych na wniosek Rady wydało też paszporty w enigmatycznie określonym celu do przeprowadzenia „niektórych spraw w księstwie Kurlandii, w mieście Mitawie”. Nakazano również gubernatorom w Rydze i Wielkim Nowgorodzie wypełniać wszelkie polecenia zlecone im przez księcia Wasilija Łukicza Dołgorukowa ${ }^{57}$. Jednocześnie jeden z obecnych przy śmierci Piotra II dygnitarzy - sztalmejster generał porucznik hrabia Paweł Iwanowicz Jaguszinskij, będący w konflikcie z częścią rodziny książąt Dołgorukowów, skierował do Mitawy swojego adiutanta, a zarazem kamerjunkra dworu holsztyńskiego Piotra Spirydonowicza Sumarokowa, polecając mu dotrzeć do księżniczki Anny Joannowny i doręczyć list, w którym pisał, by ta: „wyjechała z Mitawy niezwłocznie po zakończonej audiencji dla deputowanych, przyjmując wszystkie przedłożone jej warunki”, jednocześnie zawierzając jego radom, zaś on do chwili jej pojawienia się w Moskwie postara się liczebnie „powiększyć dla niej stronnictwo, które nie jest zadowolone z rządów Rady", informując w ślad za tym, że kanclerz hrabia Gołowkin jest już po jej stronie, „tak iż, gdy Jej Wysokość przybędzie do Moskwy, wszystko zakończy się zgodnie z jej zamiarami" ${ }^{58}$.

Delegacja Najwyższej Tajnej Rady przybyła do Mitawy prawie równocześnie z Sumarkowem ok. 25 stycznia. Anna Joannowna przyjęła zarówno tego ostatniego, jak i plenipotentów Najwyższej Tajnej Rady ${ }^{59}$. Godząc się na zaproponowane jej warunki, w liście kierowanym na adres tej instytucji, zapowiadała swój wyjazd z Mitawy do Moskwy na dzień 29 stycznia 1730 r. ${ }^{60}$ Wiadomość o treści tego pisma dotarła do mieszkańców Moskwy 2 lutego ${ }^{61}$. W tym też dniu Najwyższa Tajna Rada upubliczniła zaaprobowane przez przyszłą imperatorową punkty mające ograniczyć jej samodzierżawną władzę ${ }^{62}$. Dwa dni później wydała

por. też Kondieji ogranicziwajuszczije włast ' monarcha w polzu Wierchownowo tajnowo sowieta (naprawliennyje w Mitawu), dat. [Moskwa], 19 janwaria 1730 goda, [w:] Konstitucionnyje projekty w Rossiji..., s. 77 — które różnią się użytym słownictwem od poprzednich wykorzystanych przeze mnie wersji.

57 D.A. Korsakow, op. cit., s. 16; F. Prokopowicz, op. cit., s. 15.

58 [Ch.H. Manstein], op. cit., s. 183-184.

59 Ibidem, s. 184; D.A. Korsakow, op. cit., s. 81.

60 Otwietnoje pismo Anny Joannowny Wierchownomu tajnomu sowietu s izjawlieniem sogłasija na jewo predłożenije, dat. Mitawa, 28-go genwarja 1730-go godu, [w:] I.W. Kurukin, A.B. Płotnikow, op. cit, s. 122-123, dokument nr 3.

61 F. Prokopowicz, op. cit., s. 22.

62 Protokot ob oficjalnom ogłaszenii „,kondicij” Wierchownym tajnym sowietom pered wysszimi czinami, dat. [Moskwa], 2 fewralia 1730 g.[oda], [w:] I.W. Kurukin, A.B. Płotnikow, op. cit., s. 123-136, dokument $\mathrm{nr} 3$. 
ponadto manifest $O$ śmierci imperatora Piotra Drugiego i o przejęciu tronu rosyjskiego przez gosudarynię carewną Annę Joannowna, w którym informowano poddanych m.in. o tym, iż przyszła cesarzowa zmierza właśnie o Moskwy, a po jej zaprzysiężeniu wydane zostaną przez nią stosowne ukazy dotyczące spraw państwa i zamieszkującej go ludności ${ }^{63}$.

Plany polityczne członków Najwyższej Tajnej Rady napotkały jednak opór znacznej części zachowawczych kręgów szlachty rosyjskiej. Relacjonujący wydarzenia ze stycznia i lutego 1730 r. arcybiskup Teofan Prokopowicz pisal, iż w odpowiedzi na działania podjęte przez wierchowników

powstało inne stronnictwo, ośmioosobowemu przeciwne. Ci z wyższych sfer, to jest ze szlachty, zaczęli się porozumiewać i naradzać, jakby skutecznie przeszkodzić wierchownikom i przebiegły ich plan zburzyć, i dlatego w różnych domach w porze nocnej spotykali się ${ }^{64}$.

Relacjonował też dalej, że wśród tej grupy nie było jednomyślności co do sposobu walki z członkami Najwyższej Tajnej Rady i pojawiła się nawet koncepcja siłowego rozwiązania kwestii, aż do pozbawienia życia wierchowników ${ }^{65}$.

10 lutego dotarła do Moskwy wiadomość, iż Anna Joannowna zatrzymała się w siole Wsieswiatskoje, położonym od niej w odległości 7 wiorst ${ }^{66}$. Ze starej stolicy wyruszyła tam wówczas delegacja, w skład której weszli hierarchowie Cerkwi prawosławnej oraz kilkunastu senatorów i innych dostojników państwowych $^{67}$. Cesarzowa 14 lutego udzieliła im audiencji ${ }^{68}$, podczas której miała już wyraźnie okazywać swój dystans wobec wierchowników ${ }^{69}$. Prawie równolegle podjęła też próbę pozyskania na swoją rzecz gwardzistów z preobrażeńskiego pułku gwardii, w którym służył w randze majora jej bliski krewny Siemion Andrejewicz Sałtykow, szafując tam licznymi awansami i mianując siebie, wbrew podpisanym w Mitawie kondycjom, również pułkownikiem tejże formacji ${ }^{70}$. To właśnie żołnierze preobrażeńskiego pułku gwardii mieli w nieodległym czasie

63 Manifest ot imieni Wierchownowo Tajnowo Sowieta „O konczine Impieratora Piotra Wtorowo, i o wospriniati Rossijskowo prestoła Gosudaryniej Cariewnoj Annoj Joannownoj", dat. [Moskwa] 4 fewralia [1730 goda], [w:] Zakonodatielstwo impieratricy Anny Joannowny, red. W.A. Tomsinow, Moskwa 2017, s. 3.

64 T. Prokopowicz, op. cit., s. 17-18.

65 Ibidem.

66 Ibidem, s. 28; inne informacje podaje [Ch.H. Manstein], op. cit., s. 184 - cesarzowa miała przybyć tam 20 lutego i zatrzymać się na pięć dni; nie potwierdza tego jednak Żurnat ,pochoda” Anny Joannowy iz Mitawy w Moskwy 29 janwaria - 10 fewralia 1730 goda, [w:] I.W. Kurukin, A.B. Płotnikow, op. cit., s. 170-172, dokument nr 36 - który jako dzień jej przybycia do miejscowości Wsieswiatskoje podaje datę 10 lutego $1730 \mathrm{r}$.

67 I.A. Czistowicz, Teofan Prokopowicz i jewo wriemia, Sankt Petersburg 1868, s. 258.

68 Żurnat oficjalnoj audiencji Wierchownowo tajnowo sowieta, Senata, a także lic ,iz generaliteta i szliachectwa" u Anny Joanowny w podmoskowskom siole Wsiechswiatskom, dat. [Moskwa] 14 fewralia 1730 goda, [w:] I.B. Kyrukin, A.B. Płotnikow, op. cit., s. 172-173, dokument nr 37.

69 [Ch.H. Manstein], op. cit., s. 184-185.

70 I.W. Kurukin, A.B. Płotnikow, op. cit., s. 95. 
zabezpieczać moment, w którym cesarzowa wycofała się z przyjętych jeszcze w Kurlandii warunków ograniczających jej samodzierżawne panowanie ${ }^{71}$.

25 lutego w godzinach porannych na Kremlu zebrała się grupa kilkuset przedstawicieli szlachty niechętnych pomysłom ustrojowym wierchowników na czele z księciem Aleksiejem Michajłowiczem Czerkasskim ${ }^{72}$. Uzyskawszy audiencję u cesarzowej, doręczyli jej petycję, w której prosili monarchinię o przyjęcie samodzierżawia w takiej formie, jaka była udziałem jej ,sławnych i dostojnych przodków”. Ponadto żądali likwidacji Najwyższej Tajnej Rady i Wysokiego Senatu oraz przywrócenia wprowadzonego jeszcze przez Piotra I Senatu Rządzącego ${ }^{73}$. Wspierali ich żołnierze i oficerowie preobrażeńskiego pułku gwardii, którzy na polecenie Anny Joannowny otoczyli pałace kremlowskie i strzegli jej bezpieczeństwa ${ }^{74}$. Ku aplauzowi zgromadzonych, przy milczącej postawie wierchowników, imperatorowa oficjalnie zrezygnowała z „kondycji mitawskich”, przedzierając publicznie podpisany przez nią oryginał dokumentu je zawierającego ${ }^{75}$. Wydarzenie to kończyło pierwszą w Imperium Rosyjskim, aczkolwiek oligarchiczną, próbę ograniczenia samodzierżawia, zaś same kondycje mitawskie mogą uchodzić za pierwowzór czegoś w rodzaju karty konstytucyjnej, której jednak nie dane było obowiązywać.

\section{Bibliografia}

\section{Źródła drukowane}

Dołgorukow P.W., Wriemia imperatora Piotra II i impieratricy Anny Joannowny, Moskwa 2008.

Konstitucionyje projekty w Rossiji XVIII - naczała XX wieka, red. A.N. Mieduszewskij, Moskwa 2010.

Kurukin I.W., Płotnikow A.B., 19 janwaria - 25 fewralia 1730 goda: sobytia, liudzi, dokumenty, Moskwa 2010.

[Manstein Ch.H.], Zapiski o Rossiji generata Mansztejna, Moskwa 2008.

Naszcziokin W.A., Zapiski, [w:] J.P. Szachowskij, W.A. Naszcziokin, I.I. Nieplujew, Impierija posle Piotra 1725-1765, Moskwa 1998.

Pilsztynowa S. Proceder podróży i życia mego awantur, Kraków 1998.

[Prokopowicz T.], Istorija o izbranii i wosszestwii na prestol błażennyja $i$ wiecznodostojnyja pamiati Gosudaryni Impieratricy Anny Joannowny Samodzierżawcy Wsierossijskija soczinienije Teofana Prokopowicza 1730 god, Sankt Petersburg 1837.

Zakonodatielstwo impieratricy Anny Joannowny, red. W.A. Tomsinow, Moskwa 2017.

${ }^{71}$ [Ch.H. Manstein], op. cit., s. 186.

72 D.A. Korsakow, op. cit., s. 193, 270.

73 Dworianskoje proszenije impieratrice Annie Joannownie o wostanowlenii samodzierżawija Wierchownowo tajnowo sowieta, dat. [Moskwa] 25 fewralia 1730 goda, [w:] W.I. Kurukin, A.B. Płotnikow, op. cit., s. 142, dokument nr 10.

74 [Ch.H. Manstein], op. cit., s. 186; D.A. Korsakow, op. cit., s. 274.

75 D.A. Korsakow, op. cit., s. 277; [Ch.H. Manstein], op. cit., s. 186-187. 


\section{Opracowania}

Agiejewa O., Impieratrica Wsierossijskaja Anna Joannowna 28 janwaria 1693-17 oktiabria 1740, Moskwa 2015.

Aleksiejew A.S., Silnyje persony w Wierchownom Tajnom Sowietie Piotra II i rol kniazia Golicyna pri wocarenii Anny Joannowny, Moskwa 2016.

Anisimow E.W., Gosudarstwiennyje preobrazowanija i samodzierżawie Piotra Wielikowo, S.[ankt] Petersburg 1997.

Anisimow E.W., Imperatorskaja Rossija, Moskwa-Sankt-Petersburg-Mińsk 2016.

Anisimow E., Piotr II, [w:] Dynastia Romanowów, red. A. Iskenderow, Warszawa 1993.

Bogosłowskij M.M., Konstitucjonnyje dwiżenije 1730 goda, [w:] idem, Rossijskij XVIII wiek, t. 2, Moskwa 2010.

Boucher D., Burke, [w:] Myśliciele polityczni. Od Sokratesa do współczesności, red. D. Boucher, P. Kelly, przeł. A. Dąbrowska, T. Sieczkowski, Kraków 2008.

Brikner A.G. (Brückner), Istorija Piotra Wielikowo, Moskwa 2004.

Cypin W., Istorija Russkoj Prawostawnoj Cerkwii. Sinodalnyj i nowiejszij periody (1700-2005), Moskwa 2006.

Czistowicz I.A., Teofan Prokopowicz i jewo wriemia, Sankt Petersburg 1868.

Demkin A.W., Wnutriennaja politika Jekateriny I i Wierchownowo Tajnowo Sowieta, Moskwa 2011.

Filipow A., Istorija Senata w prawlenije Wierchownowo Tajnowo Sowieta i Kabineta, cz. 1. Senat w prawlenije Wierchownowo Tajnowo Sowieta, Juriew 1895.

Gonneau P., Lavrov A., Des Rhôs á la Russie. Histoire de l'Europe orientale (v. 730-1689), Paris 2012.

Grebielskij P., MirwisA.,Dom Romanowych. Biograficzeskijeswedenija oczlenach carstwowawszego doma, ich predkach i rodstwiennikach, S.[ankt] Petersburg 1992.

Heller M., Historia Imperium Rosyjskiego, Warszawa 2000.

Jundziłł Z., Ustrój polityczny Imperium Rosyjskiego, Londyn 1949.

Kartaszew A.W., Istorija Russkoj Cerkwi, Moskwa 2005.

Kazanskij P.E., Włast‘ Wsierossijkowo Imperatora, Moskwa 2007.

Korkunow N.M, Russkoje gosudarstwiennoje prawo, t. 1. Wwiedienije i obszcziaja czast', red. Z.D. Awałow, M.B. Gorenberg, K.N. Sokołow, S.[ankt] Petersburg 1908.

Korsakow A.D., Wocarenije imperatricy Anny Jannowny, Kazań 1880.

Kurukin I.W., Anna Iwanowna, Moskwa 2014.

Kurukin I.W., Reformy i reformatory „epochi dworcowych piereworotow”, [w:] Reformy w Rossiji $s$ drewniejszych wriemion do konca XX wieka, t. 2. XVIII — pierwaja połowina XX wieka, red. A.B. Kamienskij, Moskwa 2016.

M[alczewski] J., Pufendorf Samuel von..., [w:] Stownik historii doktryn politycznych, t. 4, red. K. Chojnicka, M. Jaskólski, Warszawa 2009.

Pawlenko N.I., Aleksandr Daniłowicz Mienszikow, Moskwa 1981.

Pawlenko N.I., Istorija Piotra Wielikowo, Moskwa 2006.

Płatonow S., Russkaja istorija, Moskwa 2015.

Talberg N., Istorija Russkoj Cerkwi, Moskwa 2008.

Taranowski T., Historia prawa rosyjskiego, cz. 1. Historia ustroju państwowego, „Pamiętnik Historyczno-Prawny" 1928, t. 6, z. 1.

Timoszina E, Feofan Prokopowicz, [w:] I.J. Kozlichin, A.W. Poliakow, E.W. Timoszina, Istorija politiczeskich i prawowych uczenij, Sankt Petersburg 2007.

Waldenberg W., Drewnierusskije uczenija o predełach carskoj własti. Oczerki russkoj polityczeskoj literatury ot Wtadimira swiatowo do konca XVII wieka, Moskwa 2006.

Władimirskij-Budanow M.F., Obzor istorii russkowo prawa, Moskwa 2005.

Wortman R.S., Scenarias of Power. Myth and Ceremony in Russian Monarchy, t. 1. From Peter the Great to the Death of Nicholas I, Princeton 1995.

Studia nad Autorytaryzmem i Totalitaryzmem 39, nr 1, 2017

(C) for this edition by CNS 


\section{THE MITAU CONDITIONS AND THE ATTEMPT TO LIMIT AUTOCRACY IN THE RUSSIAN EMPIRE IN THE EARLY 1730}

\section{Summary}

Tsarist autocracy is specific to Russia's absolute power, in which the tsar's position was superior and fully sovereign. In January of 1730 after the death of the last member of Romanov's dynasty, Tsar Peter II of Russia, the dignitaries sitting at the Supreme Privy Council decided to vest the Russian's throne to a member of the female line of this family — the Duchess of Courland, Anna Ivanovna. However, several political conditions were implemented, significantly reducing the scope of the imperial power. Their content was set out within so called "Mitau Conditions", which after acceptance was to become a sui generis constitutional document for the Russian Empire's subjects. The resistance of conservative nobles gathered in Moscow caused a complete fiasco of this initiative.

Keywords: Russian Empire, Tsarist autocracy, Peter II of Russia, The Supreme Privy Council, Anna Ivanonva, Consitution, noblemen, resistance.

Dariusz Szpoper

dariusz.szpoper@uwm.edu.pl 